\title{
Listy dotyczące osób pochodzenia kaukaskiego służących w Wojsku Polskim i działaczy ruchu prometejskiego, przechowywane w polskich archiwach w Londynie ${ }^{1}$
}

Zarys treści: W niniejszej pracy zaprezentowano listy przechowywane w archiwach Instytutu Józefa Piłsudskiego w Londynie, Instytutu Polskiego i Muzeum im. gen. Sikorskiego, a także Studium Polski Podziemnej. Dotyczą one osób pochodzenia kaukaskiego służących w armii polskiej w czasie II wojny światowej, a także kaukaskich działaczy ruchu prometejskiego, którzy pozostawali w kręgu zainteresowania polskich polityków emigracyjnych w Londynie.

Outline of content: This article outlines the lists stored in the archives of the Joseph Pilsudski Institute in London, the Polish Institute and Sikorski Museum, and Polish Underground Movement Study Trust. These documents enumerate the persons of Caucasian descent having served in the Polish army during World War II, as well as the Caucasian activists of the Promethean movement, who were of interest to Polish politicians in exile in London.

Słowa kluczowe: ruch prometejski, Kaukaz, wojsko polskie w czasie II wojny światowej, II Rzeczpospolita, oficerowie kontraktowi w armii polskiej

Keywords: Prometheism, the Caucasus, the Polish army in the Second Republic of Poland, contracting officers in Polish army

Jednym z częściej podejmowanych tematów w kwestii stosunków polsko-kaukaskich, zwłaszcza mających miejsce w okresie dwudziestolecia międzywojennego, jest zagadnienie ruchu prometejskiego. Polskie zaangażowanie w to przedsięwzięcie wynikało z przyjętej przez Józefa Piłsudskiego koncepcji bezpieczeństwa międzynarodowego odnośnie do wschodnich granic Rzeczpospolitej. Marszałek uważał, że najlepszym rozwiązaniem byłoby powstanie niepodległych państw między Polską

1 Artykuł powstał dzięki otrzymaniu przez autora stypendium Fundacji Lanckorońskich z Brzezia. 
i Rosją Radziecką, które stanowiłyby swoisty bufor ochronny. Projekt ten nie ograniczał się jedynie do ewentualnych, bezpośrednich sąsiadów Polski, jak Białoruś czy Ukraina, ale obejmował szeroki pas ziem znajdujących się na zachodzie i południu Związku Radzieckiego. W jego skład wchodził także Kaukaz. Po zajęciu tego regionu przez Armię Czerwoną w latach 1920-1921 i podpisaniu traktatu ryskiego, urzeczywistnienie projektu stworzenia kordonu ochronnego stało się nierealne. Jednakże nie odrzucono go całkowicie. Historyk wojskowości, bliski ideowo J. Piłsudskiemu, Władysław Pobóg-Malinowski² ${ }^{2}$ stał na stanowisku, że celem polskiego polityka było rozczłonkowanie Rosji i doprowadzenie jej do kształtu państwa moskiewskiego z XVI wieku ${ }^{3}$. Konsekwencją takiej pozycji było zaangażowanie Polski w ruch prometejski, a także przyjmowanie do Wojska Polskiego oficerów kontraktowych pochodzących z mniejszości etnicznych zamieszkujących Związek Radziecki.

Oba powyższe tematy są względnie często podejmowane przez polskich historyków od dłuższego czasu. Jednym z pierwszych, który zajął się całościową analizą ruchu prometejskiego, był Sergiusz Mikulicz. Rezultaty swoich badań opublikował w pracy Prometeizm w polityce II Rzeczpospolitej wydanej w 1971 roku. W następnych latach wiedza na temat prometeizmu była nieustannie pogłębiana. Obecnie zajmuje się nim grupa uczonych, wśród których cenny wkład w jego poznanie wnieśli m.in.: Jan Jacek Bruski, Marek Kornat, Paweł Libera czy Wojciech Materski. Wypada jednak zauważyć, że o ile tematyka „prometejska” i kwestia kaukaskich oficerów w Wojsku Polskim jest dość dobrze opracowana odnośnie do II Rzeczpospolitej, o tyle mało jest publikacji dotyczących losów tych żołnierzy w czasie II wojny światowej oraz po jej zakończeniu, a także dziejów ruchu prometejskiego po 1945 roku. W dużej mierze taki stan rzeczy można wytłumaczyć jego marginalizacją w ówczesnych warunkach geopolitycznych. Niemniej zagadnienie emigracyjnych związków polsko-kaukaskich przedstawia się interesująco i zasługuje na swoje studium.

Ważnym miejscem dla prowadzenia badań dotyczących powyższych tematów jest Londyn. Wynika to z tego, że był on głównym centrum skoncentrowania powojennej polskiej emigracji politycznej i siedzibą rządu na uchodźstwie. Wiele dokumentów dotyczących działalności osób zaangażowanych w powojenny ruch prometejski jest obecnie przechowywanych $\mathrm{w}$ archiwum Instytutu Józefa Piłsudskiego i archiwum Instytutu Polskiego i Muzeum im. gen. Sikorskiego. Ponadto materiały dotyczące osób pochodzenia kaukaskiego, które służyły w wojsku II Rzeczpospolitej, zgromadzono w archiwum Studium Polski Podziemnej.

W niniejszej pracy zaprezentowano listy oficerów i działaczy politycznych z Kaukazu, którzy w taki czy inny sposób byli powiązani z Polską lub pozostawali w kręgu zainteresowania polskich polityków przebywających w Londynie po zakończeniu II wojny światowej. W założeniu zabieg ten ma pomóc osobom zaintereso-

2 Władysław Pobóg-Malinowski żył w latach 1899-1962. W latach 20. XX w. pracował m.in. w Wojskowym Biurze Historycznym, a od 1931 r. był naczelnikiem Wydziału Historyczno-Naukowego w Ministerstwie Spraw Zagranicznych.

3 S. Mikulicz, Prometeizm w polityce II Rzeczpospolitej, Warszawa 1971, s. 15. 
wanym poznaniem losów oficerów kontraktowych, a także tym, którzy chcieliby pogłębić swoją wiedzę dotyczącą emigracyjnych kontaktów polsko-kaukaskich. Przedstawiony poniżej materiał ma charakter uzupełniający do istniejącej literatury przedmiotu i przybliża zainteresowanym osobom dokumenty archiwalne. Pozwalaja one na zweryfikowanie losów poszczególnych żołnierzy pochodzących z Kaukazu, którzy służyli w Wojsku Polskim podczas II wojny światowej.

W archiwum Studium Polski Podziemnej, w kolekcji 13. zatytułowanej „Tadeusz Walenty Pełczyński”, w teczce 61, znajduje się lista kaukaskich działaczy emigracyjnych wraz z miejscami ich pobytu. Dokument nie został podpisany, ale niewykluczone, że jego autorem jest Tadeusz Pełczyński. Brak także daty jego sporządzenia. Można jednak założyć, że powstał on w 2. poł. 1945 r., ewentualnie na początku 1946 roku. Wynika to głównie ze wskazań na miejsce pobytu poszczególnych osób, które odpowiada właśnie temu okresowi. Na liście nie umieszczono jedynie przedwojennych aktywistów prometejskich, ale szerszy krąg działaczy pochodzących z Kaukazu, którymi zainteresowani byli polscy politycy emigracyjni. Dokument liczy 29 nazwisk, z których większość stanowią Azerbejdżanie i mieszkańcy Kaukazu Północnego.

Spośród Azerbejdżan wymienieni zostali:
1. M. E. Rasulzade ${ }^{4}$
Ankara
2. Mustafa Wekilli ${ }^{5}$
Amasia $^{6}$
3. Mir Jakub $^{7}$
Turcja

4 Mahammad Emin Rasulzade stał na czele Rady Narodowej, która ogłosiła w maju 1918 r. powstanie Demokratycznej Republiki Azerbejdżanu. Po zajęciu Azerbejdżanu przez Armię Czerwoną M. Rasulzade został aresztowany. Uwolniono go ze względu na osobiste wstawiennictwo Józefa Stalina, który następnie spowodował przyjazd M. Rasulzadego do Moskwy, do pracy w Komisariacie ds. Narodowości. W 1922 r. Azerbejdżanin uciekł z ZSRR do Finlandii, a potem do Turcji. W 1931 r. przejechał do Polski. W Polsce M. Rasulzade był aktywnym członkiem Klubu „Prometeusz”. Jego drugą żoną była Wanda, córka Adama Piłsudskiego, brata Józefa. W czasie II wojny światowej M. Rasulzade przebywał w Niemczech, gdzie stanął na czele Narodowej Rady Azerbejdżanu. Był jednym z twórców tzw. Legionu Azerbejdżańskiego w składzie Wermachtu. Po wojnie osiadł w Turcji, gdzie zmarł w 1955 r. Z życiem i działalnością M. Rasulzade można się zapoznać w jego biografii: А. Балаева, Мамед Эмин Расулзаде (1884-1955), Москва 2009.

5 Mustafa Wekilli był jednym z liderów partii Musawat. W czasie Demokratycznej Republiki Azerbejdżanu pełnił funkcję ministra spraw wewnętrznych. Na emigracji M. Wekilli żył w Turcji, Niemczech i Francji. Był aktywnym uczestnikiem azerbejdżańskiej sekcji ruchu prometejskiego. Zmarł w 1965 r. Na temat działalności azerbejdżańskiej emigracji politycznej patrz: Из истории азербайджанской эмиграции. Сборник документов, произведений, писем, ред. С.М. Исхаков, Москва 2011.

6 Amasia to miasto w północnej Turcji.

7 Chodzi o Mir Jakuba Mechdijewa, jednego z założycieli azerbejdżańskiej panislamskiej partii Ittihad. W okresie istnienia Demokratycznej Republiki Azerbejdżanu J. Mechdijew był deputowanym do parlamentu, a także członkiem azerbejdżańskiej delegacji na konferencję pokojową w Paryżu. Po wkroczeniu Armii Czerwonej w kwietniu 1920 r. wyjechał do Turcji, gdzie wraz z M. Rasulzade brał aktywny udział w ruchu prometejskim. Zmarł w Turcji w 1952 r. O działalności J. Machdijewa patrz: Н. Агамалиева, Р. Худиев, Азербайджанская Республика. Страницы политической истории 1918-1920 2.2., Баку 1994. 
4. Achmed Dżafar Ogłu ${ }^{8}$

5. Mirza Bała ${ }^{9}$

6. Abusz Fatalibejli ${ }^{10}$

7. Aziz Ozer ${ }^{11}$

8. Mamed Tugaj ${ }^{12}$

9. Alakper Topczibaszi ${ }^{13}$

10. Mamed Amirdżan ${ }^{14}$

11. Kerim Key

\author{
Turcja \\ Turcja \\ Rzym \\ Stambuł \\ Kair \\ Paryż \\ Stambuł \\ Nowy Jork
}

8 Chodzi o Achmeda Dżafaroglu, znanego turkologa pochodzenia azerbejdżańskiego. Po wkroczeniu Armii Czerwonej wyjechał do Stambułu, gdzie kontynuował studia wcześniej rozpoczęte w Baku. Następnie A. Dżafaroglu wyjechał do Niemiec, gdzie studiował na uniwersytecie w Berlinie i Wrocławiu. W 1929 r. powrócił do Turcji i rozpoczął pracę na uniwersytecie w Stambule. W 1938 r. A. Dżafaroglu został członkiem-korespondentem Polskiej Akademii Umiejętności. Zmarł w 1975 r. Biografia A. Dżafaroglu: E. Obülhəsənli, Ohməd Cəfəroğlunun adəbiyyaţ̧ünaslıq irsi, Bakı 2006.

9 Chodzi o Mirzabala Mamedzade. W czasie istnienia Demokratycznej Republiki Azerbejdżanu pracował jako pracownik administracyjny w parlamencie w Baku, był także członkiem partii Musawat. Po zajęciu kraju przez Armię Czerwoną M. Mamedzade pracował w konspiracyjnej drukarni. Został aresztowany w 1923 r., ale szybko opuścił więzienie, po czym wyjechał w 1924 r. do Persji, a następnie do Turcji. W 1932 r. M. Mamadzade przejechał do Polski i jednocześnie publikował artykuły w gazetach wydawanych w Berlinie, których redaktorem był M. Rasulzade. Po wybuchu II wojny światowej powrócił do Turcji. Umarł w 1959 r. w Stambule. O M. Mamedzade patrz: T. Асланова, Роль М.Б. Мамдзаде в истории духовой и общественной мысли Азербайджана, „Филология. Социальные коммуникации", tom 26 (65), nr 2, 2013, s. 137-141.

10 Chodzi o Abdurrahmana Fatalibejli-Dudanginskiego. Na początku II wojny światowej służył w Armii Czerwonej i brał udział w wojnie radziecko-fińskiej. Po dostaniu się do niemieckiej niewoli A. Fatalibejli-Dudanginski zaczął współpracować z hitlerowcami, w wyniku czego wszedł w skład dowództwa jednego z batalionów azerbejdżańskich stanowiących część Wermachtu. Po wojnie przebywał w Rzymie, gdzie wydawał proislamskie i antyradzieckie broszury. W kolejnych latach A. Fatalibejli-Dudanginski żył w Egipcie i Niemczech. W 1954 r. został zamordowany przez agenta KGB. Biografia A. Fatalibejli-Dudaginskiego: N. Yaqublu, Obdürrəhman Fotəlibəyli-Düdənginski, Bakı 2009.

11 Zapewne chodzi o publicystę Aziza Ozera, którego żoną była Polka - Jadwiga. Zmarł w Stanach Zjednoczonych w $1981 \mathrm{r}$.

12 Mamed Tugaj pochodził z rejonu szemachińskiego Azerbejdżanu. Po 1920 r. wyemigrował do Turcji, a następnie do Europy, gdzie zajmował się pracą publicystyczną, m.in. w radio. W czasie wojny Tugaj brał udział w formowaniu oddziałów azerbejdżańskich w składzie Wermachtu.

13 Alekper Topczibaszi był synem Alimardana Topczibaszewa, przewodniczącego parlamentu Demokratycznej Republiki Azerbejdżanu, który po zajęciu kraju przez Armię Czerwoną żył na emigracji we Francji.

14 Mamed (w niektórych dokumentach wymieniany jest jako Murad) pochodził ze znanej rodziny azerbejdżańskiej mieszkającej w Stambule. Jego ojciec, Abdulali Amirdżanow, był ministrem finansów w Demokratycznej Republice Azerbejdżanu, który po zajęciu kraju wyemigrował do Stambułu. Natomiast brat Mameda, Fuad, współpracował przy organizacji Legionu Azerbejdżańskiego w składzie Wermachtu. Przez wiele lat w okresie międzywojennym i w czasie II wojny światowej rodzina Amirdżan/ Amirdżanow znajdowała się w opozycji do A. Rasulzadego. Patrz: Г. Мамулиа, Р. Абуталыбов, Страна огней в борбе за свободу и независимость. Политическая история азербайджанской эмиграиии 1920-1945 г2., Париж-Баку 2014. 


\section{Z Gruzinów wymieniono:}
1. Noe Żordania ${ }^{15}$
2. Gogi Nakaszydze ${ }^{16}$
3. Kote Imnadze $e^{17}$
4. Sumbatoff ${ }^{18}$
5. Guguszwili ${ }^{19}$
6. Menagari ${ }^{20}$
7. Dumbadze 21

Paryż
Niemcy
Wielka Brytania
Wielka Brytania
Wielka Brytania
Turcja
Stany Zjednoczone

15 Noe Żordania żył w latach 1869-1953. Był jednym z najbardziej wpływowych gruzińskich mienszewików, a także premierem rządu niepodległej Republiki Gruzji w latach 1918-1921. Po wkroczeniu Armii Czerwonej udał się na emigrację do Francji, gdzie kontynuował działalność polityczną. Zmarł w Paryżu w $1953 \mathrm{r}$.

16 Giorgi Nakaszydze w 1921 r. jako student-ochotnik uczestniczył w obronie gruzińskiej granicy przed atakiem Armii Czerwonej. Następnie został aresztowany przez bolszewików. W 1922 r., w wyniku wstawiennictwa ambasadora Republiki Gruzji w Niemczech, którego poparło wielu polityków europejskich, władze radzieckie wypuściły G. Nakaszydze wraz z kilkudziesięcioma innymi więźniami, którym zezwolono na wyjazd do Niemiec. Po opuszczeniu Gruzji G. Nakaszydze kontynuował studia w Heidelbergu i Pradze, jednocześnie działając w ruchu prometejskim. W 1930 r. został kierownikiem departamentu Języka Gruzińskiego i Literatury na Uniwersytecie w Berlinie, a 1933 r. zaproszono go do Warszawy, gdzie pracował w Instytucie Wschodnim i Uniwersytecie Warszawskim. W czasie II wojny światowej G. Nakaszydze współpracował z Komitetem Kaukaskim. W 1944 r., kiedy Armia Czerwona wkraczała do Polski, otrzymał od niemieckich władz okupacyjnych zgodę na wyjazd do Niemiec. Zamieszkał w Monachium. Zmarł w Nowym Jorku w 1990 r. O działalności G. Nakaszydze w Polsce można przeczytać w książce: I. P. Maj, Działalność Instytutu Wschodniego $w$ Warszawie 1926-1939, Warszawa 2007.

17 Kote (znany także pod imieniem Konrad) Imnadze w czasie istnienia niepodległej Gruzji był sekretarzem Noego Żordanii. Po zajęciu Gruzji przyjechał do Polski, gdzie został oficerem kontraktowym (dosłużył się stopnia majora). K. Imnadze był jednym z liderów społeczności gruzińskiej w Polsce i aktywnym uczestnikiem ruchu prometejskiego. Zmarł w 1957 r. w Anglii. Na temat gruzińskiej emigracji politycznej patrz: Г. Мамулиа, Борба за свободу и независимость Кавказа (1921-1945), Тбилиси-Париж 2012.

18 Najprawdopodobniej chodzi tu o Micheila Sumbataszwili (mógł on na emigracji odrzucić gruzińską końcówkę -szwili i używać francuskiej wersji rosyjskiej końcówki -ow, tj. -off). Od 1918 r. był przedstawicielem Gruzji w Bernie w Szwajcarii, następnie pracował w ambasadzie Gruzji w Paryżu. Po zajęciu Gruzji przez Armię Czerwoną M. Sumbataszwili przeniósł się do Londynu, gdzie był przedstawicielem gruzińskiego rządu emigracyjnego. Zmarł w 1954 r. w Niemczech.

19 Najprawdopodobniej chodzi o Andria Guguszwili, który w okresie niepodległości Gruzji był sekretarzem w ambasadzie tego kraju w Londynie. W 1921 r. został członkiem Komitetu dla Pomocy Gruzji. Po likwidacji ambasady gruzińskiej A. Guguszwili został wykładowcą języka gruzińskiego w Uniwersytecie Londyńskim. Zmarł w Londynie w 1970 r. Jego krótka biografia została umieszczona na stronie internetowej gruzińskiego Archiwum Państwowego: http://www.nplg.gov.ge/emigrants/ $\mathrm{ka} / 00000059 /$ (dostęp 13.09.2015).

20 Sardion Menagaria (Menagariszwili) był jednym z przywódców gruzińskich socjaldemokratów. Z Gruzji wyjechał w $1925 \mathrm{r}$. Brał czynny udział w działalności ruchu prometejskiego. Zmarł w $1960 \mathrm{r}$.

21 Trudno jednoznacznie sprecyzować, o kogo chodzi. Najbardziej znanym przedstawicielem diaspory gruzińskiej w Stanach Zjednoczonych, który nosił nazwisko Dumbadze, był Wasil. Był on przedstawicielem rządu gruzińskiego w Stanach Zjednoczonych, a także finansistą pracującym w Banku Morgana. Po zajęciu Gruzji przez Armię Czerwoną w 1921 r. Wasil Dumbadze wyjechał 
Spośród przedstawicieli różnych narodów Kaukazu Północnego na liście znaleźli się:

1. Mahmet Girej Sunsz ${ }^{22}$

2. Hajdar Bammat ${ }^{23}$

Turcja

3. Alichan Kantemir ${ }^{24}$

4. Ajtek Namitok ${ }^{25}$

Szwajcaria

5. Achmed $\mathrm{Nabi}^{27}$

6. Barasbi Bajtugan ${ }^{28}$

Mittenwald $^{26}$

Wielka Brytania

na emigrację do Europy, a w 1924 r. przeniósł się do Stanów Zjednoczonych, gdzie stał się jednym z liderów gruzińskiej społeczności. W. Dumbadze zmarł w 1943 r., a więc kilka lat przed powstaniem prezentowanej listy. Jego pojawienie się na niej można jednak wytłumaczyć tym, że jej autor prawdopodobnie nie znał daty jego śmierci.

22 Mahmet (Mamed) Girej Sunsz (Sunszew) był z pochodzenia Bałkarem. W imieniu Kaukazu Północnego w 1934 r. podpisał pakt o utworzeniu Konfederacji Kaukaskiej.

23 Hajdar Bammat był z pochodzenia Kumykiem. Urodził się w 1889 r. w Kafyr-Kumyk w Dagestanie. W 1918 r. pełnił rolę ministra spraw zagranicznych Związku Górali. Po zajęciu Kaukazu przez Armię Czerwoną H. Bammat wyjechał do Paryża. W latach 1938-1948 pracował w ambasadzie Afganistanu w Szwajcarii, a następnie powrócił do Francji. Zmarł w 1965 r. Z działalnością H. Bammata można się zapoznać w książce: Г. Мамулиа, М. Вачагаев, Х-М. Доного, Гайдар Баммат и журнал «Кавказ», Махачкала-Париж 2010.

24 Alichan Kantemir z pochodzenia był Osetyjczykiem wyznającym islam. Po utworzeniu Demokratycznej Republiki Azerbejdżanu był w niej przedstawicielem Związku Górali Kaukazu Północnego i Dagestanu. W 1921 r. wyjechał do Turcji, a w latach 30. osiadł w Niemczech. W latach 20. Kantemir brał udział w tworzeniu ruchu prometejskiego. W czasie II wojny światowej wszedł w skład dowództwa tzw. Legionu Północnokaukaskiego i stanął na czele Północnokaukaskiego Komitetu Narodowego. Po wojnie zajmował się działalnością wydawniczą i naukową. Zmarł w 1963 r. w Monachium. O działalności A. Kantemira patrz: И. Сулаев, Совет Обороны Северного Кавказа и Дагестана: неизвестные страницы истории, Махачкала 2004.

25 Ajtek Namitok był Czerkiesem urodzonym na Kubaniu. W 1917 r. aktywnie uczestniczył w formowaniu pierwszego Kubańskiego Rządu Narodowego. Był także wybrany na delegata na konferencję pokojową w Paryżu. Po 1920 r. A. Namitok pozostał na emigracji i zajmował się głównie pracą nad historią narodów Kaukazu Północnego. Umarł w Stambule w 1965 r. Patrz: И. Бабич, Казаки и западные адыги: взаимоотночения в европейскойэмиграции в 1920-е г2., „Вопросы казачей истории и кулыьтур", выпуск 9, 2013, s. 5-23.

26 Mittenwald znajduje się w Bawarii.

27 Najprawdopodobniej chodzi o urodzonego w 1897 r. Achmed-Nabi Magomę (Magomajewa) jednego z głównych organizatorów Narodowego Komitetu Północnokaukaskiego, który działał w Niemczech w czasie II wojny światowej. Po wojnie A.-N. Magoma osiadł w Monachium, gdzie zajmował się działalnością wydawniczą i nauczycielską. Zmarł w 1961 r. O współpracy emigrantów z Kaukazu z niemieckimi służbami specjalnymi można przeczytać m.in. w pracy С. Чуев, Спецслужбы Третьего Рейха, Санкт-Петербург 2003.

28 Barasbi Bajtugan był Osetyjczykiem, który walczył w oddziałach Białych. Od 1922 r. mieszkał w Czechosłowacji, a następnie we Francji, gdzie zajmował się działalnością wydawniczą i uczestniczył w ruchu prometejskim. W latach 30. B. Bajtugan przeniósł się do Warszawy, gdzie redagował czasopismo „Kaukaz Północny”. Następnie zamieszkał w Niemczech. Po wojnie przebywał w Wielkiej Brytanii, ale w 1953 r. powrócił do Niemiec. Umarł w 1986 r. w Monachium. O działalności wydawniczej B. Bajtugana czytaj: А. Рубанова, Журналы «Гориы Кавказа» и «Северный Кавказ» как источник по истории горской эмигращии, „Вестник Адыгейского государственного университета. Серия 1: 

7. Wassan Girej Dżabagi ${ }^{29}$
Mittenwald
8. inż. Bilaty ${ }^{30}$
Niemcy
9. Tambi Elikchoti ${ }^{31}$
Paryż
10. Seid Szamil ${ }^{32}$
Stambuł
11. inż. Ibrahim Hajdar Ogłu ${ }^{33}$
Ankara

Inny dokument dotyczący działaczy z Kaukazu znajduje się w archiwum Instytutu Polskiego i Muzeum im. gen. Sikorskiego. Przechowywany jest w inwentarzu 48, zatytułowanym Kancelaria Cywilna i Gabinet Wojskowy Prezydenta RP, 1939-1991, w zespole 10, w teczce E dotyczącej gminy muzułmanów polskich w Wielkiej Brytanii. Autorem dokumentu jest prawdopodobnie Leon Bohdanowicz. Nie podano daty jego powstania, lecz można szacować, że były to pierwsze lata powojenne. Brak także adresata dokumentu, aczkolwiek prawdopodobne jest, że został on sporządzony dla kręgów rządu emigracyjnego. W zestawionej liście jej autor wymienił swoich znajomych z kręgów polityczno-naukowych, wśród których część stanowiły osoby pochodzące $\mathrm{z}$ Kaukazu.

Регионоведение: философия, история, социология, юриспруденция, политология, культурология" nr 1(113), 2013, s. 45-51.

29 Wassan Girej Dżabagi był z pochodzenia Inguszem. Jako polityk aktywnie działał w Republice Górskiej, dla której współtworzył deklarację niepodległości, a także sprawował funkcję przewodniczącego komisji finansowej. Żoną W. Dżabagiego była polska Tatarka. Z tego powodu w okresie międzywojennym przez kilkanaście lat żył w Polsce, ale był sceptycznie nastawiony do ruchu prometejskiego. W 1937 r. wyjechał z rodziną do Stambułu jako korespondent Polskiej Agencji Telegraficznej. W Polsce została jednak jego córka - Dżannet, która wyszła za Polaka. W. Dżabagi zmarł w Stambule w $1961 \mathrm{r}$.

30 Bilaty (Bilati/Billati) Balo z pochodzenia był Osetyjczykiem. Po zajęciu Kaukazu przez Armię Czerwoną zamieszkał w Turcji, a w latach 30. przeniósł się do Polski, gdzie zajmował się działalnością wydawniczą, a także aktywnie działał w ruchu prometejskim. W czasie II wojny światowej B. Balo zamieszkał w Niemczech i pracował w Północnokaukaskim Komitecie Narodowym. Zmarł w 1971 r.

31 Tambi Elikchoti był osetyjskim mienszewikiem i publicystą. Brał udział w walkach północnokaukaskich górali przeciwko wojskom Denikina i Armii Czerwonej. Początkowo T. Elikchoti wyemigrował do Turcji, a następnie osiadł we Francji. Aktywnie współpracował z emigracyjnymi wydawnictwami północnokaukaskimi. Stał też na czele przedstawicielstwa Komitetu Północnokaukaskiego we Francji. Zmarł w 1952 r. w Nicei.

32 Said Szamil był z pochodzenia Awarem, wnukiem imama Szamila. Urodził się i wychowywał w Turcji. Uczestniczył w powstaniu antybolszewickim na Kaukazie Północnym w latach 1920-1921, którego jednym z przywódców był jego ojciec. W 2. poł. lat 30. zamieszkał w Warszawie i zaangażował się w działalność ruchu prometejskiego. W czasie II wojny światowej osiadł w Niemczech i wszedł w skład Północnokaukaskiego Komitetu Narodowego. Po zakończeniu wojny Said Szamil zamieszkał w Stambule, gdzie zmarł w 1981 r. O życiu i działalności Saida Szamila czytaj: А. Муртазалиев, Х.М. Доного, Мухаммад Саид Шамиль. Исторический портрет, воспоминания, публицистика, очерки, Махачкала 2003.

33 Ibrahim Hajdar (Hajdarow) był Azerbejdżaninem urodzonym w Dagestanie (w Derbencie). W 1918 r. został deputowanym w Sejmie Zakaukaskim, a także zasiadł w rządzie Zakaukaskiej Federacyjnej Republiki Demokratycznej. W 1919 r. Hajdar reprezentował Republikę Górską na konferencji pokojowej w Paryżu. Od 1920 r. żył na emigracji, najpierw we Francji, a następnie w Turcji. Zmarł w 1949 r. Biografia I. Најdara patrz: М. Абдуллаев, Ибрагим-бек Гайдаров, Махачкала 1999. 
W początkowej części dokumentu autor wyliczył stowarzyszenia, do których należał w Wielkiej Brytanii. Były to:

- Królewskie Towarzystwo Azji Centralnej (Royal Central Asian Society) znajduje się tam adnotacja, że stowarzyszenie ma charakter polityczny;

- Królewskie Towarzystwo Azjatyckie (Royal Asiatic Society) - znajduje się tam adnotacja, że stowarzyszenie ma charakter naukowy;

- Towarzystwo Muzułmańskie w Wielkiej Brytanii (Muslim Society in Great Britain) - znajduje się tam adnotacja, że autor notatki wchodził w skład zarządu;

- Londyńska Grupa Międzynarodowa (London International Group).

Autor zaznaczył także, że współpracował z:

- Królewskim Instytutem Spraw Międzynarodowych (Royal Institute of International Affairs);

- Departamentem Zagranicznych Badań Naukowych (Foreign Research Departament);

- Islamskim Centrum Kulturalnym (Islamic Cultural Centre).

Na liście umieszczono także jedno stowarzyszenie ze Stanów Zjednoczonych Amerykańskie Stowarzyszenie Mahometańskie (American Mohammedan Society), a przy nim w nawiasie zapisano Stowarzyszenie Tatarów Polskich, co sugeruje, że właśnie przez to stowarzyszenie L. Bohdanowicz, prawdopodobny autor notatki, działał w stowarzyszeniu amerykańskim. Podano także adres organizacji: 104-6-8 Power's Str., Brooklin, N.Y.

Autor dokumentu wymienił też swoich zagranicznych znajomych. Analizując tę listę, można dojść do wniosku, że były to osoby wpływowe, które w taki lub inny sposób można byłoby wykorzystać na płaszczyźnie politycznej. Spośród osób zamieszkujących Stany Zjednoczone te wyszczególnione to:

- $\quad$ Ali Mamleeff, Tatar kazański;

- H. A. Doolittle, Konsul Generalny Stanów Zjednoczonych w Aleksandrii (Egipt);

- dr E. Lindgren, była urzędniczka Królewskiego Instytutu Spraw Zagranicznych (Royal Institute of International Affairs).

Z terenu Francji na liście znajomych autora znalazły się następujące osoby:

- J. P. Palewski; przy nim uczyniono adnotację: „adwokat przy sądzie apelacyjnym w Paryżu, b. doradca prawny Ambasady R.P. w Paryżu, starszy brat Gastona, b. dyrektora gabinetu gen. de Gaulla";

- prof. J. Deny; przy nim uczyniono adnotację: „dyrektor Szkoły Języków Wschodnich";

- prof. Sauraz, przy nim uczyniono adnotację: „b. dyrektor Instytutu Francuskiego w Londynie". 
Wśród przebywających w Turcji wymienionymi osobami są:

- Ayas Ischaki z dopiskiem „lider Tatarów kazańskich”;

- Fuad Tuchtarów z dopiskiem „b. poseł do Zebrania Konstytucyjnego w Rosji w 1917 r.";

- Abubekr Sejfullin z dopiskiem „inżynier z Turkiestanu”;

- rodzina Wassan Gireja-Dżabagiego z dopiskiem „sam Dżabagi, prezes Sejmu Górali Kaukazu Pół., podobno obecnie przebywa w Niemczech";

- dr Reszad z dopiskiem "prof. wydziału lekarskiego w Stambule”;

- Kunaków z dopiskiem „góral kaukaski ${ }^{34}$ żonaty z polską Tatarką".

W dokumencie umieszczono także nazwiska osób zamieszkujących w Egipcie:

- dr Hussayin, przy którym umieszczono uwagę; „prof. uniwersytetu w Alexandrii";

- Mohammed Negib, przy którym umieszczono uwagę: „korespondent dziennika kairskiego «El Misre» (Egipcjanin)”.

Jeżeli zaś chodzi o los żołnierzy pochodzenia kaukaskiego, którzy służyli w polskim wojsku, to w Studium Polski Podziemnej znajduje się ich częściowy spis. Został on sporządzony 1 grudnia 1948 r. w Londynie przez Azerbejdżanina, Veli-bek Jedigara. Jego lista obejmuje następujące osoby:

- gen. dywizji Aleksander Zachariadze ${ }^{35}$. Przy nazwisku umieszczono informację, że podczas wojny przebywał w Warszawie i pomimo silnej presji Niemców w sprawach Kaukazu, nie zdecydował się na nawiązanie z nimi współpracy. Zanotowano także, że był w kontakcie z Polską podziemną i w tym kontekście wymieniono gen. T. Pełczyńskiego lub p. Skarzyńskiego. Zdaniem V. Jedigara w momencie sporządzania notatki Zachariadze przebywał w Niemczech.

Pod nazwiskiem A. Zachariadzego znajduje się spis oficerów, który zatytułowano „W szeregach W.P. od 1.8.1939”. V. Jedigar umieścił na niej:

$34 \mathrm{~W}$ wielu dokumentach z początku i połowy XX w. terminem „górale kaukascy” oznaczano mieszkańców Kaukazu Północnego niezależnie od ich przynależności etnicznej, tak więc mógł oznaczać Awarów, Czeczenów, Osetyjczyków i inne narody zamieszkujące region.

$35 \mathrm{~W}$ polskich dokumentach często występuje jako Zachariadze, lecz oryginalna forma brzmi

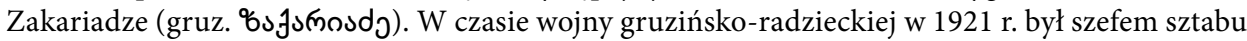
armii gruzińskiej. Następnie wraz z rządem przejechał do Turcji, aby w 1922 r. przybyć do Polski. W Polsce A. Zachariadze szkolił się w kilku szkołach wojskowych. Następnie znajdował się na wojskowym etacie, aczkolwiek nie miał przydziału i nie pełnił służby. Osoba generała wzbudzała wiele kontrowersji wśród gruzińskich oficerów zakontraktowanych w Wojsku Polskim, z których duża część obwiniała go o klęskę armii gruzińskiej w wojnie z bolszewikami w 1921 r. Po wybuchu wojny A. Zachariadze pozostał w Warszawie. Niemcy zezwolili mu na wyjazd w momencie przybliżania się Armii Czerwonej w 1944 r. Początkowo mieszkał w zachodniej części Niemiec, a następnie pojechał do Paryża. 
- $\quad$ płk Roman Gwelisiani. Przy nazwisku dopisano: „cały czas na terenie $\mathrm{WB}^{36}$. Szczegółów nie znam. Obecnie Londyn. PKPR ${ }^{37 " ;}$

- ppłk dypl. kaw. Veli b. Jedigar. Przy nazwisku dopisano: „1939, A.K., 2 korpus. Obecnie Londyn. PKPR". Znajduje się ponadto uwagą, że otrzymał on Srebrny i Złoty Krzyż Zasługi. Nazwa ostatniego odznaczenia jest podkreślona czerwonym ołówkiem i ręcznie dopisano „za AK”;

- ppłk aud. Aleksander Kipiani. Przy nazwisku dopisano: „przeszedł przez Rosję potem 2 korpus. Obecnie PKPR, Penrhos Camp, n/Pwllheli, NWeles ${ }^{38}$ ", a także „Złoty K. Zasługi z Miecz., jednakże przy tej ostatniej informacji umieszczono znak zapytania;

- $\quad$ kom. por. mar. wojennej Wiktor Lomidze. Przy nazwisku dopisano: „1939 - obrona Helu?, potem WB, obecnie PKPR";

- mjr art. Husein Kumuz ${ }^{39}$. Przy nazwisku dopisano: „1939 - dowódca dyonu ${ }^{40}$ art. 220, potem JWSW ${ }^{41}$ na placówkach spec. Obecnie Londyn. PKPR";

- mjr Melik Somchian. Przy nazwisku dopisano: „1939, Br. Karpacka (Tobruk), 2 korpus (Monte Cassino). Obecnie WB. PKPR”. Znajduje się także uwaga: „V.M.5”, co oznacza, że Somchian otrzymał order Virtuti Militari piątej klasy;

- mjr art. Aleksander Lagidze. Przy nazwisku dopisano: „1939, Rosja?, 2 korpus (Monte Cassino). Obecnie WB. PKPR". Tak jak w wypadku M. Somchiana umieszczono informację, że Lagidze otrzymał order Virtuti Militari piątej klasy;

- $\quad$ mjr geog. ${ }^{42}$ Dawid Wacznadze. Przy nazwisku dopisano: „WB. Obecnie WB. PKPR";

- mjr art. Dawid Kutateladze. Przy nazwisku dopisano: „1939, Br. Karpacka?, JWSW, Obecnie USA";

- $\quad$ kpt. art. Josuf Umaszew. Przy nazwisku dopisano: „1939, JWSW, 2 korpus. Obecnie Londyn. PKPR";

36 Tj. Wielka Brytania.

37 Polski Korpus Przysposobienia i Rozmieszczenia, który powstał w Londynie w 1946 r.

38 Chodzi tu o obóz Penrhos, który znajdował się obok Pwllheli w hrabstwie Gwynedd w północnej Walii. Funkcjonujące do czasów współczesnych osiedle Penrhos powstało w 1949 r. w celu zapewnienia mieszkań i pomocy żołnierzom służących w Wojsku Polskim, którzy po wojnie zdecydowali się pozostać w Wielkiej Brytanii. Wybudowano je na terenie bazy lotniska RAF Penrhos, gdzie po 1945 r. ulokowano obóz PKPR.

$39 \mathrm{~W}$ archiwum Instytutu Polskiego i Muzeum im. gen. Sikorskiego przechowywana jest notatka adresowana do ministra spraw zagranicznych polskiego rządu emigracyjnego w Londynie, która została sporządzona 4 stycznia 1948 r. Informuje się w niej, że mjr Hussein Kumuz, lat 58, Czerkies, w ostatnich latach do listopada 1947 r. przebywał w Kairze. Pozostając w bliskich osobistych relacjach z królem Egiptu Farukiem, miał oddać wielkie usługi dla Dowództwa Jednostek Wojska Polskiego na Środkowym Wschodzie w nawiązaniu kontaktów z oficjalnymi czynnikami egipskimi. Zaznaczono przy tym, że przed wojną był wybitnym uczestnikiem ruchu prometejskiego. W dokumencie podano także informację, że H. Kumuz w Londynie wszedł z polskiej strony do Komitetu, który powstał w celu koordynacji politycznych akcji muzułmanów.

40 Dyon - dywizjon.

$41 \mathrm{Tj}$. Jednostki Wojskowe na Środkowym Wschodzie.

42 Zapewne chodzi o służbę geograficzną. 
- kpt. mar. wojennej Tumaniszwili. Przy nazwisku dopisano: „WB, Obecnie Londyn. PKPR";

- kpt. br. panc. Szakro Cercwadze. Przy nazwisku dopisano: „1939, WB, obecnie Londyn PKPR”. Uczyniono także adnotację, że jego synem jest starszy sierżant A.K., odznaczony Krzyżem Walecznych (jednokrotnie), który także przebywa w Wielkiej Brytanii;

- kpt. piech. Dżawachiszwili. Przy nazwisku dopisano: „1939, 2 korpus; Obecnie Londyn. PKPR";

- kpt. piech. Kiknadze. Przy nazwisku dopisano: „1939?, Rosja?, 2 korpus, Obecnie Londyn. PKPR";

- $\quad$ kpt. sap. Cheladze. Przy nazwisku dopisano: „1939, Rosja?, 2 korpus, Obecnie WB. PKPR";

- kpt. dypl. piech. Jan Nanuaszwili. Przy nazwisku dopisano: „1939, 1943 przeszedł przez front do 2 korpusu. Obecnie Londyn. PKPR”. Zamieszczono także adnotację, że Nanuaszwili otrzymał Krzyż Walecznych, a przy tym w nawiasie dopisano „Bologna”. Wiąże się to zapewne z jego udziałem w bitwie o Bolonię, która miała miejsce w kwietniu 1945 r.;

- $\mathrm{rtm}$. Witaliusz Ugrechelidze. Przy nazwisku dopisano: „1939, A.K.?, 2 korpus, Obecnie WB. PKPR";

- por. piech. Hamid Korchmaz. Przy nazwisku dopisano: „1939, Rosja, 2 korpus (baza). Obecnie Egipt";

- kpr. podch. Jan Teriaszwili. Przy nazwisku dopisano: „A.K., potem 2 korpus, Obecnie WB?. PKPR”. Przy nazwisku znajduje się także uwaga: „żona ppor. A.K.?".

Na liście znajduje się także dział zatytułowany „Zaległości za kampanię wrześniową (formalne)". W nim wymienione są następujące osoby:

- $\quad$ płk piech. Mikołaj Wacznadze. Przy nazwisku umieszczono informację, że zmarł w oflagu (nie wymieniono, w którym) w 1940 roku. Zaznaczono także, że Wacznadze otrzymał za obronę Modlina Krzyż Walecznych (jednokrotnie). Autor, tj. V. Jedigar, zaznaczył, że widział legitymację, ale przyznania odznaczenia nie ogłoszono w Dzienniku oraz zapisał, że wdowa i córka M. Wacznadzego przebywają w Wielkiej Brytanii;

- płk Konstanty Kwikwidze. Przy nazwisku umieszczono informację, że otrzymał za obronę Modlina Krzyż Walecznych (jednokrotnie), lecz umieszczono przy tym znak zapytania. Zapisano także, że K. Kwikwidze przebywa w Wielkiej Brytanii jako D.P. ${ }^{43}$;

- ppłk dypl. piech. Walerian Tewzadze ${ }^{44}$. Przy nazwisku umieszczono informację, że za obronę Warszawy otrzymał Virtuti Militari piątej klasy, Jedigar

43 Skrót D.P. pochodzi od angielskiego Displaced Persons, tj. osoba przesiedlona.

$44 \mathrm{~W}$ archiwum Instytutu Polskiego i Muzeum im. Sikorskiego pod sygnaturą ŹR 20 znajduje się list wysłany przez Z. Jedigar-Kalinowską, mieszkającą w Madrycie, do przebywającego w Londynie 
zaznaczył przy tym, że widział legitymację. Ponadto świadkami nadania odznaczenia mieli być przebywający w Londynie płk dypl. T. Tomaszewski i płk dypl. K. Ziemski. Była to sprawa istotna, bo jak podkreślił autor faktu nadania odznaczenia W. Tewzadze nie umieszczono w Dzienniku. V. Jedigar zaznaczył także, że nie wiadomo, gdzie obecnie przebywał i zaproponował oznaczyć go jako zmarłego;

- ppłk d. V. B. Jedigar. Przy nazwisku umieszczono informację: „wniosek o odznaczenie bojowe leży w sztabie, przeszedł już przez komisję gen. dyw. T. Piskora";

Kolejny dział na liście zatytułowano „Należałoby wyróżnić”. Składa się on z nazwisk pięciu oficerów:

- płk dypl. kaw. Bahajedin Emir Hasan Chursz. Przy nazwisku umieszczono informację, że w 1939 r. pełnił obowiązki zastępcy dowódcy Mazowieckiej Brygady Kawalerii, a także, że został ciężko ranny w bitwie pod Suchowolą $\mathrm{w}$ dniu 25 września $1939 \mathrm{r}{ }^{45}$ i resztę wojny przebywał w szpitalach. V. Jedigar zapisał również, że B. Chursz w Szpitalu Ujazdowskim utrzymywał kontakty z A.K. poprzez majora Gepnera ${ }^{46}$. Autor listy zaznaczył, że B. Chursz $\mathrm{z}$ posiadanego paszportu tureckiego $\mathrm{w}$ czasie okupacji Polski tendencyjnie nie korzystał. Jedigar dodał, że Chursz wojnę 1918-1920 spędził w szeregach Tatarskiego Pułku Ułanów, a potem dowodził tzw. Dyonem Mahometańskim (dyon rtm. Churszyłowa). Zmarł w wyniku odniesionych ran w $1946 \mathrm{r}$. w szpitalu w Egipcie;

- $\quad$ rtm. Vassan Bek Totiew. Przy nazwisku umieszczono informację, że poległ w 1939 r. jako dowódca szwadronu 13. Pułku Ułanów Wileńskich. Ponadto zapisano, że V. Totiew za wojnę 1918-1920 został odznaczony Krzyżem Walecznych (jednokrotnie), a także, że osierocił córkę lat 15-16, która przebywa w Polsce;

- $\quad$ kpt. dypl. br. panc. Jerzy Ratyszwili. Przy nazwisku podano informację, że zaginął w Rosji, a odznaczył się jako dowódca kompanii czołgów w bitwie pod Lwowem w 1939 roku. V. Jedigar dodał, że podobno informacji na temat J. Ratyszwilego może udzielić gen. dyw. Marian Kukiel;

- por. kaw. Hasgirej Getmisz. Przy nazwisku podano informację, że zaginął on w Rosji (Katyń) i odznaczył się w bitwie nad Wisłą w szeregach 20. Pułku Ułanów im. J. Sobieskiego;

p. K. Skoczyńskiego. List jest datowany na 10 lutego 1986 r. Znajduje się w nim informacja, że płk Waliko Tewzadze podczas służby w polskim wojsku zmienił imię na Walery. W 1939 r. został on wzięty do niemieckiej niewoli, z której się po pewnym czasie wydostał i następnie wstąpił do A.K. Po powstaniu warszawskim walczył dalej przeciwko bolszewikom i z tego powodu ukrywał się aż do śmierci 13 grudnia $1985 \mathrm{r}$.

45 Bitwa pod Suchowolą była częścią większej operacji prowadzonej w okolicach Krasnobrodu.

46 Najprawdopodobniej chodzi o mjra Stanisława Gepnera, który w czasie II wojny światowej był oficerem Komendy Głównej Armii Krajowej. 
- $\quad$ rtm. Ewgraft Cuciew. Przy nazwisku podano informację, że będąc dowódcą szwadronu 12. Pułku Ułanów Podolskich, E. Cuciew został ciężko ranny w 1939 r., przy tym zapisano ze znakiem zapytania „amputowana noga”. V. Jedigar zaznaczył, że podczas pierwszej okupacji kresów wschodnich E. Cuciew przebywał na ich obszarze pod fałszywym nazwiskiem, a następnie służył w szeregach A.K. Autor notatki dodał także, że E. Cuciew posiadał córkę (lat 20-22), która przebywała w Wielkiej Brytanii, natomiast on sam mieszkał w Polsce pod fałszywym nazwiskiem. Notkę na jego temat uzupełnił informacją, że był on żołnierzem również w wojnie polsko-bolszewickiej w latach 1918-1920.

Kolejny dział na liście zatytułowano „Za służbę w A.K.”, co związane jest zapewne z propozycją autora do nagrodzenia wymienionych przez niego osób. Używana w tej części formuła pierwszej osoby odnosi się do V. Jedigara. W tej części umieszczono następujące osoby:

- ppłk d. W. Tewzadze. Przy nazwisku dopisano: „świadkowie «Sęk» i ja”;

- mjr sam. Aleksander Alawidze. Przy nazwisku dopisano: „świadek ja”;

- mjr piech. Artemi Aroniszidze. Przy nazwisku dopisano: „świadek ja”;

- rtm. Michał Kwaliaszwili. Przy nazwisku dopisano: „świadek «Sęk»” oraz „znam dokładny fakt do wyróżnienia”;

- rtm. E. Cuciew. Przy nazwisku dopisano: „świadek rtm. Tadeusz Strugalski (Londyn)";

- kpt. Wachtang Abaszydze. Przy nazwisku dopisano: „(Niemcy)”, a także „żona również w A.K.”;

- kpt. Geno Chundadze. Przy nazwisku dopisano: „zlikwidowany przez Niemców po złapaniu podczas wykonywania obowiązków. Przełożonym poległego był mjr art. Edward Nowak («Jog» - Kdt «Buraka») jest na terenie WB”;

- por. piech. Cybadze. Przy nazwisku dopisano: „na terenie okręgu Lublin”.

Dokument kończy się informacją, że A. Alawiadze, A. Aroniszidze, E. Cuciew i M. Kwaliaszwili znajdują się w Polsce, a ponadto M. Kwaliaszwili był zesłany na Syberię za udział w A.K. V. Jedigar dodał, że listę zestawił z pamięci i mogą być w niej drobne pomyłki.

W Studium Polski Podziemnej znajduje się jeszcze jedna lista, która odnosi się do osób z Kaukazu służących w Wojsku Polskim. Na dokumencie nie zapisano daty jego powstania ani autora. Składa się on z czterech części. W pierwszej wymieniono osoby, które straciły życie po 1 września 1939 r., składa się z następujących nazwisk:

- płk Mikołaj Wacznadze, Gruzin. Przy nazwisku dopisano: „Oflag IIIA ${ }^{47 ” ; ~}$

- ppłk dr Tabidze, Gruzin. Przy nazwisku dopisano: „Katyń”;

- ppłk dypl. Walerian Tewzadze, Gruzin. Przy nazwisku zamieszczono informację, że Tewzadze otrzymał Virtuti Militari piątej klasy;

47 Oflag III A był usytuowany w Luckenwalde w Brandenburgii, ok. $60 \mathrm{~km}$ na południe od Berlina. 
- płk dypl. Muhamed Israfil Bej, Azerbejdżanin;

- płk dypl. Bahaeddin Emir Hasan Hursz ${ }^{48}$, góral kaukaski;

- mjr Teriaszwili, Gruzin. Przy nazwisku podano rok 1939;

- mjr Siamaszwili, Gruzin;

- mjr Gulditi Kosta, Góral Kaukaski. Przy nazwisku dopisano: „Katyń”;

- mjr Mamaladze Jerzy, Gruzin. Przy nazwisku dopisano: „Katyń”;

- $\quad$ kpt. dypl. Macharadze Łado, Gruzin. Przy nazwisku zamieszczono informację, że Łado otrzymał Virtuti Militari piątej klasy;

- $\quad$ rtm. Wassan Bek Totiew, góral kaukaski. Przy nazwisku podano rok 1939;

- $\quad$ rtm. Michał Kwaliaszwili, Gruzin. Przy nazwisku dopisano „A.K.”;

- $\quad$ kpt. Geno Chundadze, Gruzin. Przy nazwisku dopisano „A.K.”;

- kpt. dypl. Ratiszwili, Gruzin. Przy nazwisku zamieszczono informację o otrzymaniu przez Ratiszwilego orderu Virtuti Militari piątej klasy;

- $\quad$ kpt. Rusiaszwili Jerzy, Gruzin. Przy nazwisku dopisano: „Katyń”;

- $\quad$ kpt. pilot Schirtładze Arkady, Gruzin. Przy nazwisku dopisano: „Katyń”;

- por. Getmisz Hasgirej, góral kaukaski. Przy nazwisku podano rok 1939;

- ppor. Tabidze, Gruzin. Przy nazwisku dopisano: „Katyń”;

- $\quad$ por. Cybadze, Gruzin. Przy nazwisku dopisano „A.K.”;

- $\quad$ kpt. int. Kobiaszwili Aleks, Gruzin;

- kpt. Kawtaradze Jan, Gruzin.

W drugiej części listy wymieniono oficerów, którzy byli na Zachodzie. Wśród nich znaleźli się:

- gen. dyw. Zachariadze Aleksander, Gruzin;

- płk dypl. Alikow Mikołaj, góral kaukaski;

- płk Dżahangir Kazum Bek, Azerbejdżanin;

- mjr dypl. Szalikaszwili D., Gruzin;

- $\quad$ rtm. dypl. Kobiaszwili Siko, Gruzin;

- rtm. Bakradze Jan, Gruzin;

- $\quad$ kpt. Merełaszwili Giga, Gruzin;

- $\quad$ kpt. Łagidze, Gruzin;

- $\quad$ kpt. Abaszydze Wachtang, Gruzin. Przy nazwisku dopisano „A.K.”;

- por. Safar Kiazym, Azerbejdżanin. Przy nazwisku dopisano odręcznie długopisem „Turcja”.

W trzeciej części wymieniono oficerów przebywających w Wielkiej Brytanii. Użyty przy nazwisku skrót PKPR oznacza, że dana osoba należała do Polskiego Korpusu Przysposobienia i Rozmieszczenia, natomiast D.P. oznacza osoby przesiedlone (ang. Displaced Persons):

$48 \mathrm{~W}$ niektórych polskich dokumentach nazwisko to zapisywane jest w formie „Chursz", natomiast w innych w formie „Hursz”. Jeżeli oprzeć się na zasadach transkrypcji alfabetu rosyjskiego, poprawną formą będzie „Chursz”. 
- płk Gwelisiani Roman, Gruzin, PKPR;

- $\quad$ płk Kwikwidze Konstanty, Gruzin, D.P.;

- $\quad$ płk Bagrationi Aleksandr, Gruzin, D.P.;

- ppłk dypl. Jedigar Wali, Azerbejdżanin, PKPR;

- ppłk Kipiani Aleksandr, Gruzin, PKPR;

- $\quad$ kmdr Łomidze Wiktor, Gruzin, PKPR;

- mjr Łagidze Aleksander, Gruzin, PKPR. Przy nazwisku umieszczono także informację o otrzymaniu przez Łagidze Virtuti Militari piątej klasy;

- mjr Kumuz Husein, góral kaukaski, PKPR;

- mjr Somchian Melik, Ormianin, PKPR. Przy nazwisku umieszczono także informację o otrzymaniu przez Somchiana Virtuti Militari piątej klasy;

- mjr d. Kutateladze Dawid, Gruzin, Stany Zjednoczone;

- $\quad$ mjr Wacznadze Dawid, Gruzin, PKPR;

- $\quad$ mjr Kutateladze Bidzina, Gruzin, D.P.;

- mjr Gogoberidze Borys, Gruzin, D.P.;

- kpt. Dżawachiszwili, Gruzin, PKPR.

- $\quad$ kpt. d. Nanuaszwili Jan, Gruzin, PKPR;

- $\quad$ kpt. Cheładze, Gruzin, PKPR;

- $\quad$ kpt. Kiknadze, Gruzin, PKPR;

- $\quad$ kpt. Umasz Jusow, góral kaukaski, PKPR;

- $\quad$ kpt. Tumaniszwili, Gruzin, PKPR;

- $\quad$ kpt. Margoti Majram Bek, góral kaukaski, PKPR;

- $\quad \mathrm{rtm}$. Ugrechelidze Witali, Gruzin, PKPR;

- $\quad$ rtm. Malsag Sozyrko, góral kaukaski, D.P.;

- $\quad$ rtm. Nacwiliszwili Parnoaz, Gruzin, D.P.;

- $\quad$ kpt. Klimiaszwili Dawid, Gruzin, D.P.;

- por. Korhmaz Hamid, Azerbejdżanin, Egipt;

- $\quad$ mjr Pawleniszwili Jerzy, Gruzin, D.P.;

- $\quad$ kpt. Cercwadze Szakro, Gruzin, PKPR.

Kolejna sekcja listy zatytułowana została „Znajdują się na Wschodzie - losy nieznane". Umieszczono na niej następujących oficerów i przy części z nich zaznaczono przynależność do Armii Krajowej:

- mjr Alawidze Aleksander, Gruzin, A.K.;

- mjr Aroniszidze Artemi, Gruzin, A.K.;

- $\quad$ kpt. d. Matykaszwili Mikołaj, Gruzin, A.K.;

- kpt. Cytłanadze Tadeusz, Gruzin;

- $\quad$ kpt. Takajaszwili Platon, Gruzin, A.K.;

- $\quad$ kpt. Zautaszwili Józef, Gruzin;

- $\quad$ kpt. Turaszwili Michał, Gruzin, A.K.;

- $\quad$ kpt. Łobżanidze, Gruzin;

- rtm. Cuciew Ewgraft, góral kaukaski, A.K. 
Ostatnia z prezentowanych list przechowywana jest w archiwum Instytutu Polskiego i Muzeum gen. Sikorskiego. Pod sygnaturą B.3339 znajduje się dokument, w którym zestawiono miejsce pochówku Gruzinów mieszkających w Wielkiej Brytanii. Wśród nich znajdują się także te osoby, które służyły w wojsku II Rzeczpospolitej. Brak autora dokumentu. Powstał on w 1. poł. 1992 roku. Sugeruje to zarówno fakt, że ostatnie umieszczone na liście osoby zmarły właśnie $\mathrm{w}$ tym roku, ale również pieczątka z datą „07 APR 1992” - nie wiadomo jednak, czy jest to dzienna data zestawienia listy czy data wpłynięcia jej do polskiej instytucji. Dokument sporządzony został w języku gruzińskim i angielskim, a ponadto każde nazwisko zostało zapisane zarówno za pomocą alfabetu gruzińskiego, jak i cyrylicy. Całość świadczy, że powstał on w kręgach gruzińskiej emigracji. Listę zatytułowano w języku gru-

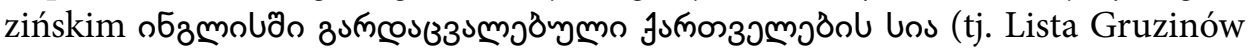
zmarłych w Anglii), należy jednak zaznaczyć, że znajdują się na niej osoby pochowane w całej Wielkiej Brytanii. Są to:

- Warlam Czerkeziszwili, zmarł 1927 r., został pochowany na cmentarzu w Kentish Town ${ }^{49}$ (skremowany);

- Silibistro Szalamberidze, zmarł prawdopodobnie w 1919 r. (rok opatrzono znakiem zapytania) w szpitalu Middlesex ${ }^{50}$;

- pułkownik Sidamon-Eristawi, przy nazwisku znajdują się dwa znaki zapytania, co oznacza, że nie znana była data śmierci i miejsce pochowania;

- Petre Dżakeli, zmarł prawdopodobnie w 1936 r. (rok opatrzono znakiem zapytania), został pochowany na cmentarzu Golders Green ${ }^{51}$ (skremowany);

- Tamara Dżakeli, zmarła w 1941 r. i została pochowana na cmentarzu Golders Green (skremowana);

- Kote Dżakeli, przy nazwisku znajdują się dwa znaki zapytania, co oznacza, że nieznana była data śmierci i miejsce pochowania;

- Nino Dżakeli, w roku zgonu zapisano znak zapytania, została pochowana na cmentarzu w Golders Green (skremowana);

- płk Roman Gwelesiani, zmarł w 1949 r. i został pochowany na cmentarzu Brompton $^{52}$, numer grobu 169148, sekcja J 245/95;

- Dawid (Dodik) Czawczawadze, zmarł 23 kwietnia 1953 r. i został pochowany na cmentarzu Hither Green ${ }^{53}$, numer grobu nieznany, sekcja NN/2;

- Aleksandre Parma, zmarł w maju 1953 r. w Limerick ${ }^{54}$ w Irlandii;

- kpt. Dawid Klimiaszwili, zmarł 1 grudnia 1953 r. i został pochowany na cmentarzu Brompton Cementary, numer grobu 198661, sekcja J 235/60;

49 Kentish Town to jedna z centralnych dzielnic Londynu.

50 Szpital Middlesex znajduje się w rejonie Fitzrovia w centralnym Londynie.

51 Cmentarz Golders Green znajduje się przy krematorium o tej samej nazwie i usytuowany jest w północno-zachodniej gminie Londynu, London Borough of Barnet.

52 Cmentarz Brompton jest położony w dzielnicy Earl's Court w Londynie.

53 Cmentarz Hither Green znajduje się w gminie Lewisham w Londynie.

54 Limerick to miasto położone w środkowo-zachodniej Irlandii. 
- płk Nikoloz Kandelaki, data śmierci nieznana, został pochowany na cmentarzu w Wrexham ${ }^{55}$;

- ppłk Giorgi Pawleniszwili, data śmierci nieznana, zmarł w Edynburgu;

- Ioseb Gwaramadze, data śmierci nieznana, został pochowany na cmentarzu Gunnersbury ${ }^{56}$;

- Kote Imnadze, data śmierci nieznana, zmarł w Bristolu;

- ppłk Walodia Lagidze, data śmierci nieznana, zmarł w Cardiff;

- płk Konstantine Kwikwidze, data śmierci nieznana, został pochowany na cmentarzu w Wrexham;

- Elene Kutateladze, zmarła 28 grudnia 1958 r., została pochowana na cmentarzu Streatham Park ${ }^{57}$, numer grobu 42809, sekcja J 235/60;

- mjr Bidzina Kutateladze, zmarł 5 maja 1958 r., został pochowany na cmentarzu Streatham Park, numer grobu 42809, sekcja J 235/60;

- $\quad$ kmdr por. Wiktor Lomidze, zmarł 30 czerwca 1956 r., pochowany został na cmentarzu Brompton, numer grobu 201425, sekcja J 20646;

- kpt. Farnaoz Nacwliszwili, zmarł 11 grudnia 1956 r., pochowany został na cmentarzu Brompton, numer grobu 201747, sekcja P/41/18;

- Aleksandre Sumbataszwili, data śmierci i miejsce pochówku nie znane;

- Iliko Zerekidze, prawdopodobny rok śmierci 1966 (został on opatrzony znakiem zapytania), pochowany na cmentarzu Kensal Rise ${ }^{58}$;

- ppłk Aleksandre Kipiane, zmarł między rokiem 1966 a 1969, pochowany został na cmentarzu New Hammersmith ${ }^{59}$;

- Żorżeta Gambaszidze Stiuartisa, data śmierci nieznana, została pochowana w Kinlochmoidart ${ }^{60}$ w Szkocji;

- kpt. Taliko Ugrechelidze, data śmierci nieznana, został pochowany w Londynie;

- mjr Irakli Kiknadze, data śmierci nieznana, został pochowany w Londynie;

- mir Melik Somchianci, data śmierci nieznana, został pochowany w Londynie;

- Andro Guguszwili, prawdopodobny rok śmierci to 1970 (opatrzono go znakiem zapytania, został skremowany w Londynie, przy nazwisku znajduje się informacja w języku gruzińskim: „,jednakże jego prochy zostały rozrzucone (zgodnie z jego wolą) w sadzie rodzinny Allenów, znajdującym się 100 kilometrów od Londynu, co było rodzinną tradycją)";

- Rażden Rusiszwili, data śmierci nieznana, został pochowany w Ely ${ }^{61}$;

55 Wrexham to miasto położone w północno-wschodniej Walii.

56 Cmentarz Gunnersbury znajduje się w gminie Royal Borough of Kensington and Chelsea w Londynie. Warto zaznaczyć, że na cmentarzu tym spoczywa wielu polskich działaczy emigracyjnych i dowódców wojskowych, m.in. Józef Haller, Tadeusz Komorowski i Kazimierz Sawicki.

57 London Borough of Lambeth.

58 Cmentarz Kensal Rise znajduje się w gminie Royal Borough of Kensington and Chelsea w Londynie.

59 Chodzi o cmentarz Mortlake, który znany jest także jako cmentarz New Hammersmith. Znajduje się on w gminie The London Borough of Richmond upon Thames w Londynie.

60 Kinlochmoidart jest niewielką osadą na zachodzie Highland w Szkocji.

61 Ely to miasto we wschodniej Anglii, w hrabstwie Cambridgeshire. 
- mjr Gogi Dżawachiszwili, data śmierci nieznana, został pochowany we wspólnej mogile w Leuville we Francji;

- Besarion Mascharaszwili, data śmierci nieznana, został pochowany w Londynie;

- mjr Dawid Wacznadze, data śmierci nieznana, został pochowany w Londynie;

- Dawid Metreweli, data śmierci nieznana, został pochowany w Londynie;

- Iuri Czopodze, zmarł w roku 1990, został pochowany w Londynie;

- Żora Paszaliszwili, zmarł w roku 1991, został pochowany w Londynie;

- Sandro Bokeria, zmarł w roku 1991, został pochowany Redin ${ }^{62}$;

- Misza Gogiaszwili, zmarł w roku 1992, został pochowany w Londynie.

Przedstawione listy świadczą, że część powojennej polskiej emigracji politycznej $\mathrm{w}$ dalszym ciągu zainteresowana była kooperacją z przedstawicielami narodów zamieszkujących Kaukaz w ramach idei ruchu prometejskiego, który ukształtował się w latach 20. XX wieku. Należy jednak mieć na uwadze, że po II wojnie światowej prometeizm stracił jednego z głównych swoich sponsorów i propagatorów - Polskę. Polscy działacze polityczni przebywający na Zachodzie, pozbawieni wsparcia państwa, nie mieli już takich możliwości finansowych i organizacyjnych, jakie posiadali przed wojną. Wypada także zastanowić się nad samą zasadnością wspierania ruchu prometejskiego, na który poszło wiele środków i pracy, a który de facto nie przyniósł żadnych realnych korzyści zarówno Polsce, jak i narodom zamieszkującym Kaukaz. Interesująca jest opinia na jego temat mjra Aleksandra Hauke-Nowaka ${ }^{63}$. Znajduje się ona w dokumencie przechowywanym w archiwum Instytutu Józefa Piłsudskiego w Londynie, w zespole nr 100 zatytułowanym Archiwum Stefana Mayera, pod sygn. 136. A. Hauke-Nowak obarczył w nim za nieprzygotowanie do wojny z Niemcami obóz piłsudczyków, zwłaszcza gen. Kazimierza Sosnkowskiego, który miał odrzucić propozycję Brytyjczyków utworzenia porozumienia czterech państw: Polski, Niemiec, Wielkiej Brytanii i Rosji. Generał miał nie dopuścić do niego, gdyż był on czołowym zwolennikiem prometeizmu, modnego wówczas kierunku w kołach sanacyjnego oddziału II, którego pogrobowcem jest niejaki Charaszkiewicz ${ }^{64}$, major naszego Amgotu ${ }^{65}$. Liczył wiec, że przy pomocy takich bezrobotnych pótinteligentów oddziału II, uda mu się rozbić Rosje na małe państewka, a po tym pójdzie z Niemcami na Wschód. Unikano owego porozumienia z Rosją. Nie opracowano w Sztabie Głównym od roku 1926 aż do śmierci Piłsudskiego żadnych planów wojennych odnoszących się

62 Nazwa miasta w dokumencie jest napisana niewyraźnie. Najprawdopodobniej zapisano ją w formie „Redin.”. Być może chodzi o miasto Reding w północno-wschodniej Francji.

63 Aleksander Hauke-Nowak żył w latach 1896-1956. Od czasu uzyskania przez Polskę niepodległości w 1918 r. do 1931 r. był zawodowym żołnierzem. W latach 1933-1938 A. Hauke-Nowak był wojewodą łódzkim, a następnie wojewodą wołyńskim. W okresie II wojny światowej przebywał w Wielkiej Brytanii, a po jej zakończeniu wyjechał do Ameryki Południowej.

64 Chodzi o Edmunda Charaszkiewicza, przed wojną oficera w Oddziale II Sztabu Generalnego zajmującego się ruchem prometejskim, który po zakończeniu II wojny światowej włączył się w jego odbudowanie.

65 Autor nawiązuje tu do AMGOT-u - the Allied Military Government for Occupied Territories, tj. sojuszniczej administracji wojskowej. 
do zachodniego frontu [...]. Tak więc część społeczeństwa polskiego widziała w ruch prometejskim bezsensowną stratę pieniędzy, czasu i wysiłku, ponieważ w realiach geopolitycznych dwudziestolecia międzywojennego jego założenia i cele nie miały najmniejszych szans powodzenia. Nie można jednak pominąć faktu, że jednym $\mathrm{z}$ jego istotnych wymiarów było kontraktowanie w polskiej armii oficerów pochodzących z narodów nierosyjskich, które znalazły się w Związku Radzieckim. Wielu $\mathrm{z}$ nich poniosło najwyższą ofiarę w okresie II wojny światowej, broniąc Polski przed zewnętrzną agresją. Przytoczone w artykule dokumenty stanowią świadectwo, że w polskich kręgach emigracyjnych istniała grupa ludzi, którzy chcieli ustrzec przed zapomnieniem ich wkład w obronę niepodległości emigracyjnej ojczyzny.

\title{
The lists of persons of Caucasian origin having served in the Polish Army and of activists of the Promethean movement in the Polish archives in London
}

This article outlines the lists stored in the archives of the Joseph Pilsudski Institute in London, the Polish Institute and Sikorski Museum, and Polish Underground Movement Study Trust. The lists enumerate the persons of Caucasian descent having served in the Polish army during World War II, as well as the Caucasian activists of the Promethean movement, who were of interest to Polish politicians in exile in London. The following documents are anal: a list of political activists from the Caucasus, who were of interest to the Polish government-in-exile in London; a list, probably compiled by Leon Bohdanowicz, relating to his friends from the scientific and political spheres; a list of officers of Caucasian origin having served in the Polish army, created by Veli bek Jedigar; another list of officers of Caucasian origin serving in the Polish army; and finally, a list detailing the burial places of Georgians in the UK, among which were also people serving in the Polish army.

Translated by Jakub Perliński

\begin{abstract}
Письма, касающиеся лиц кавказского происхождения, служивших в Польской армии и деятелей прометейского движения, хранящиеся в польских архивах Лондона
\end{abstract}

В статье были представлены письма, хранящиеся в архивах Института Юзефа Пилсудского в Лондоне, Польского института и Музея им. ген. Сикорского, а также Студиума Подпольной Польши. Они касаются лиц кавказского происхождения, служивших в Польской армии в период Второй мировой войны, а также кавказских деятелей прометейского движения, которые оставались в кругу интересов польских эмиграционных политиков в Лондоне. Были представлены следующие документы: список политических деятелей из Кавказа, которые оставались в кругу интересов польского эмиграционного правительства; список, вероятно составленный Леоном Богдановичем, касающийся его знакомых из политико-научных кругов; список офицеров с Кавказа, которые служили в Польской армии, составленный Вели-беком Едигаровым; следующий список офицеров кавказского происхождения, служивших в Польской армии; а также список, касающийся захоронений грузин в Великобритании, среди которых находились и лица, служившие в Польской армии. 


\section{Bibliografia:}

Т. Асланова, Роль М.Б. Мамдзаде в истории духовой и общественной мысли Азербайджана, „Филология. Социальные коммуникации”, tom 26 (65), nr 2, 2013, s. 137-141.

М. Абдуллаев, Ибрагим-бек Гайдаров, Махачкала 1999.

Н. Агамалиева, Р. Худиев, Азербайджанская Республика. Страницы политической истории 1918-1920 2.2., Баку 1994.

И. Бабич, Казаки и западные адыги: взаимоотночения в европейскойэмиграции в 1920-е 22., „Вопросы казачей истории и кулыьтур”, выпуск 9, 2013, s. 5-23.

А. Балаева, Мамед Эмин Расулзаде (1884-1955), Москва 2009.

Из истории азербайджанской эмиграиии. Сборник документов, произведений, писем, ред. С.М. Исхаков, Москва 2011.

E. Obülhəsənli, Әhməd Cəfəroğlunun adəbiyyatşünaslıq irsi, Bakı 2006.

Г. Мамулиа, Р. Абуталыбов, Страна огней в борбе за свободу и независимость. Политическая история азербайджанской эмиграции 1920-1945 г2., Париж-Баку 2014.

Ireneusz P. Maj, Działalność Instytutu Wschodniego w Warszawie 1926-1939, Warszawa 2007.

Г. Мамулиа, Борба за свободу и независимость Кавказа (1921-1945), Тбилиси-Париж 2012.

Г. Мамулиа, М. Вачагаев, Х-М. Доного, Гайдар Баммат и журнал «Кавказ», Махачкала-Париж 2010.

S. Mikulicz, Prometeizm w polityce II Rzeczpospolitej, Warszawa 1971.

А. Муртазалиев, Х.М. Доного, Мухаммад Саид Шамиль. Исторический портрет, воспоминания, публицистика, очерки, Махачкала 2003.

А. Рубанова, Журналь «Гориы Кавказа» и «Северный Кавказ» как источник по истории горской эмиграции, „Вестник Адыгейского государственного университета. Серия 1: Регионоведение: философия, история, социология, юриспруденция, политология, культурология" nr 1(113), 2013, s. 45-51.

И. Сулаев, Совет Обороны Северного Кавказа и Дагестана: неизвестные страницы истории, Махачкала 2004.

С. Чуев, Спецслужбы Третьего Рейха, Санкт-Петербург 2003.

N. Yaqublu, Obdürrahman Fotəlibəyli-Düdənginski, Bakı 2009.

Przemysław Adamczewski - doktor nauk humanistycznych, kaukazoznawca prowadzący wielopłaszczyznowe badania regionalne. Po uzyskaniu stopnia naukowego doktora na Uniwersytecie im. A. Mickiewicza w Poznaniu pracował w Wyższej Szkole Humanistyczno-Ekonomicznej w Sieradzu. Od kwietnia 2013 r. prowadzi badania naukowe w Instytucie Historii i Etnologii im. I. Dżawachiszwili w Tbilisi w ramach uczestnictwa w programie Mobilność Plus. (adprzem@op.pl) 